\title{
ASSESSMENT OF THE POSSIBILITIES FOR DETERMINING THE CHANNEL ENVIRONMENTAL FLOW BASED ON THE ENVIRONMENTAL REQUIREMENTS OF ICHTHYOFAUNA AND MACROZOOBENTOS
}

\author{
Jerzy Grela ${ }^{\bowtie}$, Paweł Madej ${ }^{\bowtie}$ \\ MGGP S.A., ul. Juliusza Lea 112, 30-133 Kraków
}

\begin{abstract}
Aim of the study

The purpose of the article is to present the effects of work on developing a method for determining environmental channel flows that could be implemented as a tool for assessing the degree of possible use of water resources by humans without compromising the functioning of the broadly understood environment. Such a method is considered as an alternative to methods of minimum acceptable flow used so far in Poland, including for example the Kostrzewa method.
\end{abstract}

\begin{abstract}
Material and methods
34 research catchments were analysed, diversified in terms of abiotic and biotic factors. In the first phase of work, the focus was on the living conditions of ichthyofauna and a simple hydrological formula was used to estimate the minimum flows in rivers, determined on the basis of the MesoHABSIM habitat model. Next the method was extended to include environmental requirements of macrozoobenthos. The relationship between environmental flow and water depth was developed for macrozoobenthos
\end{abstract}

\begin{abstract}
Results and conclusions
A hybrid method was proposed, combining habitat requirements for fish and macrozoobenthos. A set of hydrological formula coefficients was included, making it possible to calculate the value of the environmental flow for each river in Poland and each of the 4 bio-periods of the year, provided that the mean annual low flow (MALF) value is known. The authors compared the value of environmental flows obtained by this method with those obtained by the Kostrzewa method, in the analysis of data from 345 river ganges. The summary indicates the weaknesses of the method, resulting from the diversity of the hydrological regime within one biotic type and the effects of averaging the coefficients.
\end{abstract}

Keywords: environmental flows, habitat methods, hydrological formula

\section{INTRODUCTION}

Environmental flow is a modified natural flow - in such a way that these modifications, resulting from the need to provide people with access to water at the level necessary for life and development, guarantee the right amount of water needed to maintain good status of water and ecosystems that depend on the supply of water. Environmental flow refers to all the features of the hydrological regime of the wa-

凶e-mail: jerzy.grela@mggp.com.pl, pawel.madej@mggp.com.pl 
tercourse. In practice, we refer to some features of the hydrological regime, formulating restrictions on their modification. In the present work, the abovementioned the definition is reduced to the concepts of low flow component of environmental flow (channel environmental flow), i.e. a restriction aimed at maintaining the minimum flow in the river that would guarantee the good status of biological elements of water status, and the high flow component of environmental flow determining the good status of habitats and species dependent on waters. Good status should be considered according to the definition given in the Water Framework Directive (WFD) and the Habitats Directive, i.e. as one characterized by a low level of disturbance of biological values of quality elements in relation to natural conditions. In the case of heavily modified watercourses, we replace good status with good potential.

Methods for determining environmental flows are divided into 4 groups (cf. Tharme 2003):

- hydrological methods usually assuming relationship between the amount of water in the watercourse and environmental conditions, and most often determining the minimum required flow e.g. Tennant (1976) method - but also comprehensively referring to the features of the flow regime - Indicators of Hydrological Alteration (Richter et al., 1996; Olden and Poff, 2003);

- hydraulic methods assuming the relationships between hydraulic measures of watercourses such as depth or wetted perimeter, and environmental conditions for selected species, usually fish (Jowett, 1997);

- habitat methods, taking into account the environmental requirements of selected species, usually determined on the basis of field tests on a micro scale - IFIM (Bovee, 1982), PHABSIM (Milhous et al., 1989); or meso-scale - MesoHABSIM (Parasiewicz et al., 2013);

- holistic methods aimed at integrating the needs of people and ecosystems, often using expert knowledge - e.g. Building Block Method (Arthington, 1998).

The introduction of the methodology for determining environmental flows is one of the important elements of implementing the provisions of the Water Framework Directive (European Commission, 2015).
Their introduction is associated with more comprehensive restrictions (compared to those pertaining to minimum acceptable flow) to the changes in the hydrological regime of watercourses; nonetheless, determining the low flow limit below which water abstraction from the river is prohibited is one of its elements. This element, here called channel environmental flow, is the equivalent of the minimum acceptable flow, and it is the subject of this article.

Many methods have been developed in Poland for determining the minimum acceptable flow. These methods were reviewed, among others, in the work (Witowski et al., 2008), and comparisons of their results for specific catchments can be found in the work (Pusłowska-Tyszewska and Tyszewski, 2014), among others. Two of these methods, belonging to the group of hydrological methods, were indicated in the Regulation of the Minister of the Environment for use in the procedures of issuing water law permits (Regulation, 2004), containing pro-environmental elements. The first of these methods is the Kostrzewa method covering the hydrobiological criterion (linking the minimum acceptable flow dependent to MALF and the coefficient dependant on the type of catchment and its size), and the criterion of fishing and angling (taking into account the survival of fish during spawning, development and wintering periods, and determining the minimum acceptable flow as the lowest of the mean monthly low flows in individual phases of life). The second method is the Małopolska method, where the minimum acceptable flow, variable in each month, was adopted as the value of the mean monthly low flow for good status/potential, or the average between the lowest and mean low flow in a given month for moderate status/potential. This was the first attempt in Poland to link the minimum acceptable flow to the requirements of the EU Water Framework Directive.

Many methodological works concerned taking into account environmental requirements even before the concept of environmental flow began to be used. These were methods taking into account fish living conditions, e.g. modelling of critical water conditions for indicator organisms (Parasiewicz and Dunbar, 2001), determination of minimum acceptable flows using the IFIM method for the Świnna Poręba and Katy-Myscowa reservoirs (Grela, Stoch- 
liński, 2005) or macrosozoobenthos living conditions (Więzik and Więzik, 2006). From 2014, works began to appear in Poland specifically dealing with the concept of environmental flow. Methodology-focused papers have been published on the consideration of environmental requirements in the context of a full hydrological regime (Pusłowska-Tyszewska and Rycharski, 2015), as well as comparative studies covering the results of the application of various methods as illustrated with examples of selected catchments (Pusłowska-Tyszewska et al., 2016), (Młyński and Wałęga, 2015).

In the years $2014-2018$, two projects were carried out in Poland at the request of the National Water Management Authority, related to determining environmental flows for Polish conditions, with the intention of implementing them in the next WFD planning perspective 2021-2027. In the first project (KZGW, 2015a), a simplified hydrological formula was proposed, in which the environmental channel flow, similarly to the minimum acceptable flow according to the Kostrzewa formula (Kostrzewa, 1977), depends on the product of the mean annual low flow (MALF) and the coefficients differentiated throughout the year. These coefficients were determined on the basis of field studies, using the MesoHABSIM habitat model (Parasiewicz et al., 2013) taking into account the changing environmental conditions of the ichthyofauna development and existence throughout the year. These studies were carried out in a small number of 7 research catchments, including 4 out of 6 ichthyological types proposed for Poland (KZGW, 2015a, Parasiewicz et al., 2018).

One of the objectives of the second project (KZGW 2017, 2018a, 2018b) was the verification and calibration of the proposed method in 34 research catchments (see: Fig. 1) covering all ichthyological types, including catchments with different status (natural, heavily modified). This task was completed, and the results were published in the paper (Grela and Madej, 2019).

This project also aimed to propose the final method for determining environmental flows, after analysing the possibility of including in this method the living conditions of macrozoobenthos. Hence, the concept of field studies in selected catchments included not only 3 -fold hydromorphological studies and the fishing for ichthyofauna, but also 2-fold sampling and determination of macrozoobenthos (KZGW, 2017).

The task was implemented using the results of parallel work on updating the Water Management Plans for the next planning period 2021--2027. Particularly important were the results of work on a new typology of surface waters (KZGW, 2015b), which were designated for flowing waters in Poland, including 20 abiotic types, 6 ichthyological types, and 6 macrozoobenthos types. Each biocenotic type is associated with one or more abiotic types as follows:

Ichthyological-subdivision types:

Type 1 - mountain and upland rivers and streams (PGT, PGS, RW_krz, RsW_krz, RW_wap, RsW_wap)

Type 2 - flysch rivers (Rwf_wap, Rwf_krz)

Type 3 - lowland streams ( $\mathrm{PNp}, \mathrm{PN})$

Type 4 - lowland rivers (RzN, RwN)

Type 5 - inter-lake salmon rivers (Pl_poj, Rl_poj)

Type 6 - peat, inter-lake and estuary rivers (Pn_uj, Rzn_uj, P_org, R_org, P_poj, R_poj)

Types according to macrozoobenthos:

Type I - Tatra mountain streams (PGT)

Type II - Sudeten mountain streams and western silicate upland rivers (PGS, RW_krz, RsW_ krz)

Type III - eastern carbonate and silicate upland rivers (RW_wap, RsW_wap, Rwf_wap, Rwf_krz)

Type IV - small lowland rivers ( $\mathrm{PNp})$

Type V - lowland rivers and estuary rivers (PN, RzN, RwN, Pn_uj, Rzn_uj)

Type VI - organic lowland rivers and lowland rivers connecting the lakes ( $\mathrm{Pl} \_$poj, Rl_poj, $\mathrm{P}$ org, R_org, P_poj, R_poj)

Below (in Table 1), new abiotic types are listed in relation to the above ichthyological and macrozoobenthic types. As shown, in Poland, 10 types of aquatic environment can be distinguished, in which there is one ichthyological type and one type of macrozoobenthos.

The occurrence in Poland of these types of aquatic environment is very diverse. The table below (see: Table 2) illustrates the lengths of surface water bodies (SWB) of rivers and streams summed up within individual types, on a scale of the country as a whole. 
Grela, J., Madej, P. (2019). Assessment of the possibilities for determining the channel environmental flow based on the environmental requirements.... Acta Sci. Pol., Formatio Circumiectus, 18 (4), 59-70. DOI: http://dx.doi.org/10.15576/ASP.FC/2019.18.4.59

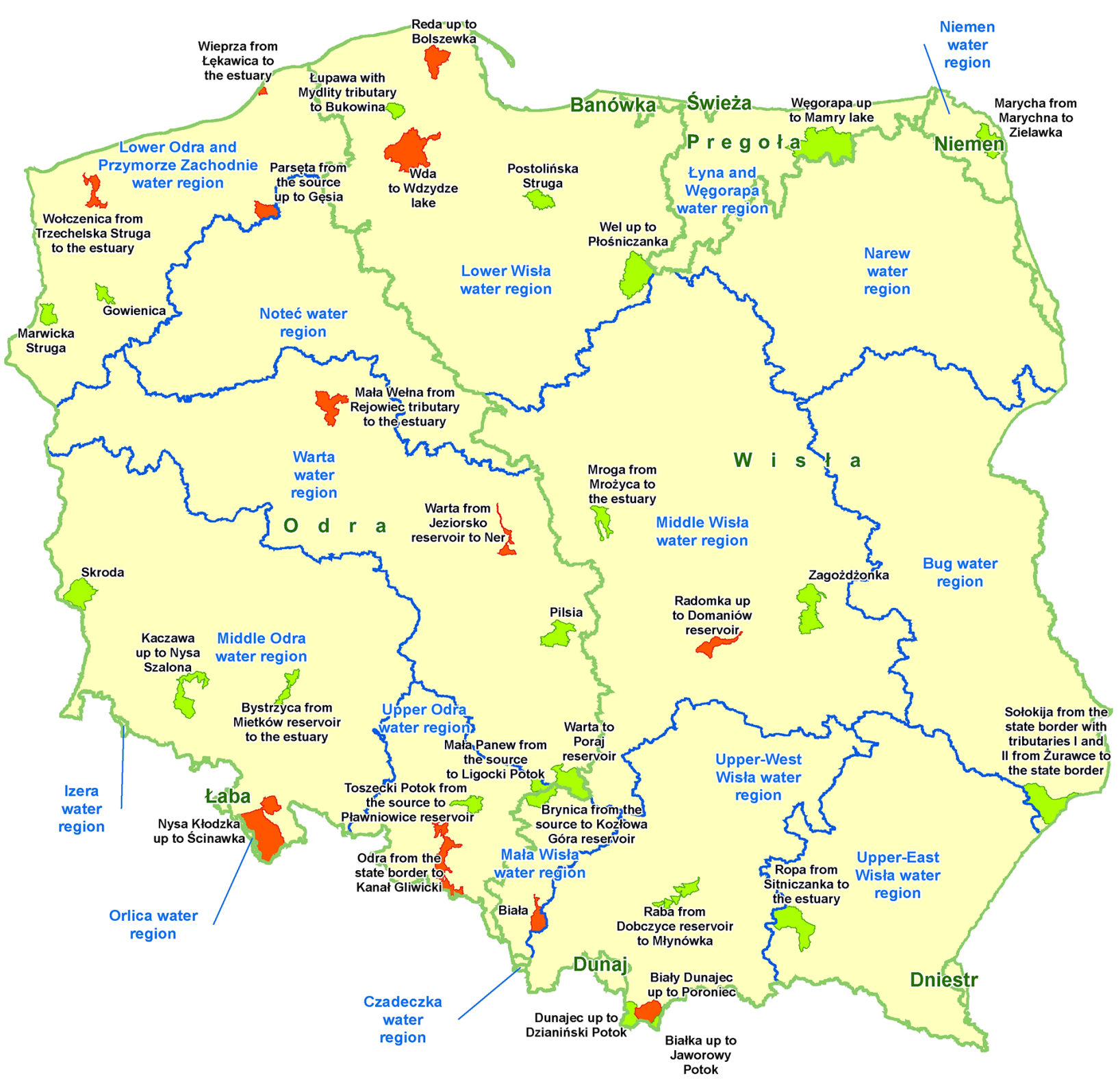

Fig. 1. Location of studied catchments in particular water regions and basin area (natural catchment areas marked in green, heavily modified catchments marked in orange) 
Grela, J., Madej, P. (2019). Assessment of the possibilities for determining the channel environmental flow based on the environmental requirements.... Acta Sci. Pol., Formatio Circumiectus, 18 (4), 59-70. DOI: http://dx.doi.org/10.15576/ASP.FC/2019.18.4.59

Table 1. Abiotic types in relation to the ichthyological and macrozoobenthic types

\begin{tabular}{|c|c|c|c|c|c|c|c|}
\hline \multirow{2}{*}{\multicolumn{2}{|c|}{$\begin{array}{c}\text { BIOCENOTIC } \\
\text { TYPES }\end{array}$}} & \multicolumn{6}{|c|}{ ICHTHYOLOGICAL TYPES } \\
\hline & & 1 & 2 & 3 & 4 & 5 & 6 \\
\hline \multirow{6}{*}{$\begin{array}{l}\text { MACRO- } \\
\text { ZOOBENTHOS } \\
\text { TYPES }\end{array}$} & I & PGT & - & - & - & - & - \\
\hline & II & $\begin{array}{l}\text { PGS, RW_krz, } \\
\text { RsW_krz }\end{array}$ & - & - & - & - & - \\
\hline & III & RW_wap RsW_wap & $\begin{array}{l}\text { Rwf_wap } \\
\text { Rwf_krz }\end{array}$ & - & - & - & - \\
\hline & IV & - & - & $\mathrm{PNp}$ & - & - & - \\
\hline & $\mathrm{V}$ & - & - & $\mathrm{PN}$ & RzN RwN & - & PN_uj RzN_uj \\
\hline & VI & - & - & - & - & Pl_poj Rl_poj & $\begin{array}{l}\text { P_org R_org } \\
\text { P_poj R_poj }\end{array}$ \\
\hline
\end{tabular}

Table 2. Listing of the length of watercourses (in $\mathrm{km}$ ) of particular biocenotic types in Poland

\begin{tabular}{|c|c|c|c|c|c|c|c|}
\hline \multirow{2}{*}{\multicolumn{2}{|c|}{ BIOCENOTIC TYPES }} & \multicolumn{6}{|c|}{ ICHTHYOLOGICAL TYPES } \\
\hline & & 1 & 2 & 3 & 4 & 5 & 6 \\
\hline \multirow{6}{*}{$\begin{array}{l}\text { MACRO- } \\
\text { ZOOBENTHOS } \\
\text { TYPES }\end{array}$} & I & 158 & - & - & - & - & - \\
\hline & II & 3810 & - & - & - & - & - \\
\hline & III & 10174 & 6990 & - & - & - & - \\
\hline & IV & - & - & 43091 & - & - & - \\
\hline & $\mathrm{V}$ & - & - & 11289 & 15778 & - & 153 \\
\hline & VI & - & - & - & - & 785 & 14938 \\
\hline
\end{tabular}

The above analysis shows that if one considered the development of a method for determining the channel flow based on the living conditions of ichthyofauna and macrozoobenthos together, the diversification should apply to 10 types of environment. Of course, in each of the above cases it should be assumed that the method will allow to determine the environmental flow for any given river throughout Poland.

\section{RESEARCH METHODOLOGY}

It was assumed that the simplified formula allowing the calculation of environmental channel flows for the final target method is identical to the one proposed by the contractor (KZGW 2015a), and it takes the following form:

$$
Q_{\hat{S R}}=p \cdot \mathrm{MALF}_{\text {unit }} \cdot A
$$

where:

p - tabulated value of the coefficient for the given catchment area, determined on the basis of pilot studies, varied for individual bio-periods,

$\mathrm{MALF}_{\text {unit }}$ - specific mean annual low flow, $\left[\mathrm{m}^{3} \cdot \mathrm{s}^{-1} \cdot \mathrm{km}^{-2}\right]$, determined by referring the MALF of the given watercourse in the examined cross-section to the catchment area of that watercourse up to this cross-section,

A - the catchment surface area up to the tested cross-section, $\left[\mathrm{km}^{2}\right]$.

The method for determining the environmental flow based on the above hydrological formula, practically based on MALF values, combining fish requirements and macrozoobenthos requirements (MesoHABSIM + Hyd_ben) was analysed.

In the case of the method based on the MesoHABSIM model, the goal was to determine the $\mathrm{p}$ coeffi- 
cients for the hydrological formula (1) based on the results of field tests processed in the habitat model according to the methodology contained in the works (KZGW, 2015a; Parasiewicz et al. 2013). When determining the abovementioned coefficients, we have included the results from work (KZGW 2018b) ${ }^{1}$.

For the habitat method based on macrozoobenthos, the assumption was to generalize the dependence of the environmental flow on the hydromorphological features of the river (in effect on the depth), and to develop on this basis a simplified method for determining the environmental flow, based on field studies of the hydraulic features of the given watercourse (KZGW 2018a, 2018b). When planning field studies, we followed the opinion of the experts, who believed that hydrological conditions are most important for the life of macrozoobenthos in spring and autumn, and in other bio-periods they are not so important. Therefore, there were no grounds to identify $\mathrm{p}$ coefficients for the remainder of the year, which ultimately led to the resignation from considering this method as a separate method.

On the other hand, the results of calculations of the environmental flow based on the macrozoobenthos requirements were used to develop the hybrid method, by combining them with the results calculated based on the MesoHABSIM model. The model based on macrozoobenthos determines the environmental flow for the spring (April-June) and autumn (September-November) periods, therefore for the spring and autumn spawning periods two environmental flow values appear, one for ichthyofauna, and the other, different one, for macrozoobenthos. In such cases, a simple rule was applied, namely that the environmental flow value would be taken as the higher of these values, according to the following formula:

$$
Q_{\text {SR }}=\max \left(Q_{\text {MezoHABSIM }}, Q_{\text {Hyd_ben }}\right)
$$

where:

$Q_{\text {ŚR }}$ - environmental flow required for biological life in the river $\left[\mathrm{m}^{3} \cdot \mathrm{s}^{-1}\right]$;
$\mathrm{Q}_{\text {MezoHABSIM }}$ - environmental flow required for the ichthyofauna $\left[\mathrm{m}^{3} \cdot \mathrm{s}^{-1}\right]$;

$\mathrm{Q}_{\text {Hyd_ben }}-$ environmental flow required for living needs of macrosozoobenthos $\left[\mathrm{m}^{3} \cdot \mathrm{s}^{-1}\right]$.

\section{RESEARCH RESULTS AND THEIR ANALYSIS}

Hydromorphological studies and macrozoobenthos uptake carried out in the project (KZGW, 2018a) allowed the calculation of environmental flows required for the proper functioning of biological life in 34 studied catchment areas. Comparison of the results for reference sections in spring and autumn, taking into account formula (2), demonstrated that:

- in 17 catchments, the environmental requirements are determined by the needs of living and development of ichthyofauna throughout the year $\left(\boldsymbol{Q}_{\mathrm{SR}}=\boldsymbol{Q}_{\text {MezoHABSIM }}\right)$,

- in 7 catchments, the environmental requirements for spring and autumn are determined by the living needs of macrosozoobenthos $\left(\boldsymbol{Q}_{\mathrm{SR}}=\boldsymbol{Q}_{\mathrm{Hyd} \_ \text {ben }}\right)$,

- in 6 catchments, in spring, the environmental conditions of fish are decisive, and in autumn, those of macrozoobenthos,

- in 4 catchments, in spring, the environmental conditions of macrosozoobenthos are decisive, and in autumn, those of fish.

In total, out of 68 studied periods ( 34 catchments $\times 2$ periods), the requirements for the volume of environmental flow for macrozoobenthos were rated higher in 24 cases, i.e. in $35 \%$. On the other hand, there were no clear regularities associated with ichthyological or macrozoobenthic types, except one that no higher requirements for macrozoobenthos than for ichthyofauna were found in ichthyological type 4.

It was decided that the coefficients for the hydrological formula would be determined based on the requirements of both models. For the 34 sections studied, the larger of the two environmental flows was adopted, and based on this set of data, the p coefficients in bio-periods were averaged.

\footnotetext{
${ }^{1}$ In the results presented in this article, simplification was applied, consisting in abandoning the separation of rivers in which autumn spawning occurs. These rivers have different assignment of calendar months to bio-periods - autumn (autumn spawning) and winter (wintering).
} 
Grela,J., Madej, P. (2019). Assessment of the possibilities for determining the channel environmental flow based on the environmental requirements.... Acta Sci. Pol., Formatio Circumiectus, 18 (4), 59-70. DOI: http://dx.doi.org/10.15576/ASP.FC/2019.18.4.59

The final values of $\mathrm{p}$ coefficients have been presented in the table (see: Table 3). It contains values of the $\mathrm{p}$ coefficient for individual 4 bio-periods and 10 areas of the aquatic environment, in which there is one ichthyological type and one macro-benthic type, developed on the basis of field studies of 34 catchments analysed in the work (KZGW 2018b). This set of 40 values can be considered as the final result of the work within the project on formulating a method for determining the environmental flow based on the requirements of ichthyofauna and macrozoobenthos.

The values of environmental flow according to the presented method were compared with the values of the minimum acceptable flow (Qn) according to the parametric method of Kostrzewa (Kostrzewa, 1977), determined on the basis of the MALF, river type and catchment area enclosed within a river-gauge cross-section, according to the simplified hydrological formula. Comparison of calculation results for the reference river sections covered by the tests is presented in the tables below (see: Table 4, Table 5).

Table 3. Values of p coefficient for the simplified methods based on the MesoHABSIM model and the requirements of the macrozoobenthos (Hyd_ben)

\begin{tabular}{ccccc}
\hline \multirow{2}{*}{$\begin{array}{c}\text { Ichthyological/ } \\
\text { macrozoobenthos } \\
\text { type }\end{array}$} & \multicolumn{4}{c}{ p coefficient } \\
\cline { 2 - 5 } & Spring & Summer & Autumn & Winter \\
\cline { 2 - 5 } & III-VI & VII-IX & X-XII & I-II \\
\hline $1 / \mathrm{I}$ & 2.36 & 1.94 & 2.24 & 1.2 \\
\hline $1 / \mathrm{II}$ & 2.15 & 1.06 & 1.56 & 1.36 \\
\hline $1 / \mathrm{III}$ & 1.5 & 0.86 & 1.14 & 1.22 \\
\hline $2 / \mathrm{III}$ & 1.25 & 0.93 & 1.11 & 1.6 \\
\hline $3 / \mathrm{IV}$ & 1.71 & 1.31 & 1.94 & 1.57 \\
\hline $3 / \mathrm{V}$ & 1.32 & 0.85 & 1.8 & 1.17 \\
\hline $4 / \mathrm{V}$ & 1.03 & 0.74 & 1.57 & 1.53 \\
\hline $5 / \mathrm{VI}$ & 1.21 & 1.11 & 1.78 & 1.34 \\
\hline $6 / \mathrm{V}$ & 1.1 & 1.31 & 1.1 & 1.39 \\
\hline $6 / \mathrm{VI}$ & 1.08 & 0.77 & 1.78 & 1.43 \\
\hline
\end{tabular}

The results for 34 reference river sections presented in Tables 4 and 5 show the differences between the individual methods. The values of channel environmental flow based on the requirements of the MesoHABSIM + Hyd_ben model are more focused when it comes to the ratio to MALF than the minimum acceptable flow calculated according to the Kostrzewa method, and generally, outside the summer period, they are higher than the minimum acceptable flow. This applies especially to the autumn period. On the other hand, the hydrological model based on habitat models sometimes produces values above the mean annual flow.

To compare the Kostrzewa method with the formula based on MesoHABSIM and the macrozoobenthos requirements model, an additional analysis was performed on a group of 345 river-gauges (KZGW, 2018b). The results of these comparative analyses are presented in the table (see: Table 6) and described below.

Having analysed the position of the minimum acceptable flows according to the Kostrzewa method in the flow ranges, we can conclude that $11 \%$ of them are below the AMF (we do not take into account the correction resulting from the method, requiring in such cases the increase of the minimum acceptable flow to the AMF value). Another $47 \%$ of cases are between AMF and MALF (including 44 cases where the minimum acceptable flow is equal to MALF) and $42 \%$ are between MALF and MAF.

In turn, the environmental flow based on the hydrological formula combining the requirements of the MesoHABSIM and Hyd_ben models is usually greater than MALF, which is the rule for spring, autumn and winter. In the vast majority of cases it remains in the range between MALF and MAF, while in $1 \%$ of cases for spring and winter and in $4 \%$ of cases for autumn it is higher than MAF. Only for the summer environmental flows smaller than MALF dominate - in over $83 \%$ of cases. In this period, flows are also smaller than minimum acceptable flows calculated according to the Kostrzewa method, which produces values not exceeding MALF only in $58 \%$ of cases.

Comparison of both methods was also conducted by averaging the values of environmental flow in respective bio-periods. The results of the comparison are as follows:

- in approx. $25 \%$ of cases, on average within one year, $Q_{\mathrm{SR}}$ is lower than $Q_{n}$ (slightly lower, up to $22 \%$ ),

- in approx. $45 \%$ of cases, on average within one year, $Q_{\mathrm{SR}}$ remains between $\mathrm{Qn}$ and $2 \cdot Q_{n}$,

- in approx. $30 \%$ of cases, on average within one year, $\mathrm{Q}_{\mathrm{SR}}$ is greater than $2 \cdot Q_{n}$ (including 2 cases in the range above $2.5 \cdot Q_{n}$ ). 
Grela, J., Madej, P. (2019). Assessment of the possibilities for determining the channel environmental flow based on the environmental requirements.... Acta Sci. Pol., Formatio Circumiectus, 18 (4), 59-70. DOI: http://dx.doi.org/10.15576/ASP.FC/2019.18.4.59

Table 4. Listing of channel environmental flows for reference river sections, according to the methods subjected to comparison

\begin{tabular}{|c|c|c|c|c|c|c|c|c|c|c|c|}
\hline \multirow{3}{*}{ River } & \multirow{3}{*}{$\begin{array}{l}\text { Abiotic } \\
\text { type }\end{array}$} & \multirow{3}{*}{$\begin{array}{l}\text { Ichthyo } \\
\text { logical } \\
\text { type }\end{array}$} & \multirow{3}{*}{$\begin{array}{c}\text { Macro } \\
\text { benthos } \\
\text { type }\end{array}$} & \multirow{2}{*}{$\begin{array}{c}\text { Absolute } \\
\text { minimum } \\
\text { flow } \\
\text { AMF }\end{array}$} & \multirow{2}{*}{$\begin{array}{c}\text { Mean } \\
\text { annual } \\
\text { low flow } \\
\text { MALF }\end{array}$} & \multirow{2}{*}{$\begin{array}{c}\text { Mean } \\
\text { annual } \\
\text { flow } \\
\text { MAF }\end{array}$} & \multirow{2}{*}{$\begin{array}{c}\text { Qn } \\
\text { according } \\
\text { to } \\
\text { Kostrzewa } \\
\end{array}$} & \multicolumn{4}{|c|}{$\begin{array}{l}Q_{\text {ŚR }}=p \cdot \text { MALF (according to } \\
\text { MesoHABSIM + Hyd_ben) }\end{array}$} \\
\hline & & & & & & & & Spring & Summer & Autumn & Winter \\
\hline & & & & \multicolumn{8}{|c|}{$\mathrm{m}^{3} \cdot \mathrm{s}^{-1}$} \\
\hline Brynica & RW_krz & 1 & II & 0.025 & 0.126 & 0.765 & 0.160 & 0.252 & 0.162 & 0.208 & 0.158 \\
\hline Dunajec & PGT & 1 & I & 0.186 & 0.680 & 3.089 & 1.034 & 1.363 & 0.876 & 1.122 & 0.855 \\
\hline Białka & PGT & 1 & I & 0.269 & 0.648 & 3.840 & 0.985 & 1.299 & 0.835 & 1.069 & 0.815 \\
\hline Ropa & RWf_wap & 2 & III & 0.576 & 1.788 & 9.644 & 1.377 & 2.231 & 1.663 & 1.977 & 2.858 \\
\hline Zagożdżonka & $\mathrm{PNp}$ & 3 & IV & 0.109 & 0.397 & 2.271 & 0.504 & 0.616 & 0.448 & 0.747 & 0.560 \\
\hline $\begin{array}{l}\text { Postolińska } \\
\text { Struga }\end{array}$ & $\mathrm{PNp}$ & 3 & IV & 0.056 & 0.145 & 0.496 & 0.145 & 0.225 & 0.164 & 0.273 & 0.205 \\
\hline Łupawa & $\mathrm{PN}$ & 3 & $\mathrm{~V}$ & 0.392 & 0.684 & 1.064 & 0.869 & 1.061 & 0.772 & 1.287 & 0.965 \\
\hline Raba & RsW_krz & 1 & II & 0.300 & 3.530 & 11.455 & 2.718 & 7.074 & 4.547 & 5.825 & 4.438 \\
\hline Mroga & $\mathrm{RzN}$ & 4 & $\mathrm{~V}$ & 0.297 & 0.883 & 2.243 & 1.121 & 0.913 & 0.656 & 1.384 & 1.350 \\
\hline Wel & R_poj & 6 & VI & 0.560 & 1.144 & 2.178 & 1.453 & 1.238 & 1.008 & 1.878 & 1.626 \\
\hline Sołokija & RW_wap & 1 & III & 0.254 & 0.725 & 1.339 & 0.921 & 1.453 & 0.934 & 1.196 & 0.911 \\
\hline $\begin{array}{l}\text { Warta do zb. } \\
\text { Poraj }\end{array}$ & RW_wap & 1 & III & 0.216 & 0.956 & 2.066 & 1.214 & 1.916 & 1.231 & 1.577 & 1.202 \\
\hline Toszecki Potok & $\mathrm{PN}$ & 3 & $\mathrm{~V}$ & 0.019 & 0.111 & 0.591 & 0.141 & 0.172 & 0.125 & 0.209 & 0.157 \\
\hline Pilsia & PN & 3 & $\mathrm{~V}$ & 0.100 & 0.347 & 1.458 & 0.441 & 0.538 & 0.392 & 0.653 & 0.489 \\
\hline Marwicka Struga & $\mathrm{PN}$ & 3 & $\mathrm{~V}$ & 0.002 & 0.048 & 0.187 & 0.048 & 0.074 & 0.054 & 0.090 & 0.068 \\
\hline Skroda & $\mathrm{PNp}$ & 3 & IV & 0.010 & 0.149 & 1.016 & 0.189 & 0.231 & 0.168 & 0.280 & 0.210 \\
\hline Bystrzyca & $\mathrm{RzN}$ & 4 & $\mathrm{~V}$ & 0.607 & 1.360 & 5.787 & 1.047 & 1.406 & 1.010 & 2.131 & 2.079 \\
\hline Mała Panew & P_org & 6 & VI & 0.021 & 0.066 & 0.320 & 0.084 & 0.071 & 0.058 & 0.108 & 0.094 \\
\hline Gowienica & P_poj & 6 & VI & 0.022 & 0.137 & 0.324 & 0.174 & 0.148 & 0.121 & 0.225 & 0.195 \\
\hline Kaczawa & RW_wap & 1 & III & 0.297 & 0.686 & 2.319 & 0.871 & 1.375 & 0.884 & 1.132 & 0.862 \\
\hline Radzieja & R_poj & 6 & VI & 0.021 & 0.084 & 0.247 & 0.107 & 0.091 & 0.074 & 0.138 & 0.119 \\
\hline Marycha & RI_poj & 5 & VI & 0.243 & 0.628 & 1.531 & 0.798 & 0.759 & 0.696 & 1.119 & 0.843 \\
\hline Biały Dunajec & PGT & 1 & I & 0.221 & 0.535 & 2.261 & 0.813 & 1.072 & 0.689 & 0.883 & 0.673 \\
\hline Biała & RWf_krz & 2 & III & 0.308 & 0.961 & 2.693 & 1.461 & 1.199 & 0.894 & 1.062 & 1.536 \\
\hline Reda & $\mathrm{PNp}$ & 3 & IV & 0.726 & 0.991 & 1.636 & 1.259 & 1.537 & 1.118 & 1.865 & 1.398 \\
\hline Radomka & $\mathrm{PNp}$ & 3 & IV & 0.010 & 0.107 & 0.440 & 0.136 & 0.166 & 0.121 & 0.201 & 0.151 \\
\hline Wda & RI_poj & 5 & VI & 1.400 & 1.994 & 3.026 & 2.532 & 2.411 & 2.211 & 3.553 & 2.677 \\
\hline Parsęta & $\mathrm{PNp}$ & 3 & IV & 0.214 & 0.446 & 1.059 & 0.566 & 0.692 & 0.503 & 0.839 & 0.629 \\
\hline Odra & RzN & 4 & $\mathrm{~V}$ & 4.220 & 9.543 & 42.258 & 4.772 & 9.868 & 7.087 & 14.955 & 14.588 \\
\hline $\begin{array}{l}\text { Warta od zb. } \\
\text { Jeziorsko }\end{array}$ & $\mathrm{RzN}$ & 4 & V & 16.455 & 30.706 & 52.845 & 15.353 & 31.753 & 22.803 & 48.119 & 46.938 \\
\hline Wołczenica & RzN & 4 & $\mathrm{~V}$ & 0.139 & 0.486 & 1.971 & 0.617 & 0.503 & 0.361 & 0.762 & 0.743 \\
\hline Grabowa & RzN_uj & 6 & V & 3.620 & 5.754 & 7.945 & 6.732 & 6.225 & 5.071 & 9.444 & 8.180 \\
\hline Mała Wełna & PI_poj & 5 & VI & 0.103 & 0.510 & 2.292 & 0.510 & 0.617 & 0.565 & 0.909 & 0.685 \\
\hline Nysa Kłodzka & RW_krz & 1 & II & 0.142 & 0.610 & 3.682 & 0.927 & 1.222 & 0.786 & 1.007 & 0.767 \\
\hline
\end{tabular}


Grela,J., Madej, P. (2019). Assessment of the possibilities for determining the channel environmental flow based on the environmental requirements.... Acta Sci. Pol., Formatio Circumiectus, 18 (4), 59-70. DOI: http://dx.doi.org/10.15576/ASP.FC/2019.18.4.59

Table 5. Placement of the calculated environmental flows within flow ranges, for the reference river sections, according to the methods subjected to comparison

\begin{tabular}{|c|c|c|c|c|c|}
\hline \multirow{3}{*}{ Flow range } & \multirow{2}{*}{$\begin{array}{c}Q_{n} \\
\text { according to } \\
\text { Kostrzewa }\end{array}$} & \multicolumn{4}{|c|}{$\begin{array}{c}Q_{\text {ŚR }}=\mathrm{p} \cdot \text { MALF } \\
\text { (according to } \\
\text { MesoHABSIM } \\
+ \text { Hyd_ben) }\end{array}$} \\
\hline & & 培 & 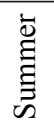 & 䒠 & 离 \\
\hline & \multicolumn{5}{|c|}{$\mathrm{m}^{3} \cdot \mathrm{s}^{-1}$} \\
\hline$<\mathrm{AMF}$ & 1 & 0 & 0 & 0 & 0 \\
\hline $\mathrm{AMF}-0,5(\mathrm{AMF}+\mathrm{MALF})$ & 1 & 0 & 1 & 0 & 0 \\
\hline $0,5(\mathrm{AMF}+\mathrm{MALF})-\mathrm{MALF}$ & 6 & 0 & 11 & 0 & 0 \\
\hline MALF - 0,5 (MALF+MAF) & 25 & 30 & 22 & 24 & 29 \\
\hline $0,5(\mathrm{MALF}+\mathrm{MAF})-\mathrm{MAF}$ & 1 & 3 & 0 & 6 & 4 \\
\hline$>$ MAF & 0 & 1 & 0 & 4 & 1 \\
\hline
\end{tabular}

Table 6. Placement of the environmental flows, calculated using different methods, within particular flow ranges (results based on the calculations for the multiannual period 1987-2016 for 345 river-gauges)

\begin{tabular}{|c|c|c|c|c|c|}
\hline \multirow{3}{*}{ Flow range } & \multirow{2}{*}{$\begin{array}{c}Q_{n} \\
\text { according } \\
\text { to } \\
\text { Kostrzewa }\end{array}$} & \multicolumn{4}{|c|}{$\begin{array}{c}Q_{\text {SR }}=p \cdot \text { MALF } \\
\text { (according to } \\
\text { MesoHABSIM }+ \\
\text { Hyd_ben) }\end{array}$} \\
\hline & & 品 & 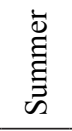 & $\underset{\Xi}{\stackrel{\Xi}{\Xi}}$ & 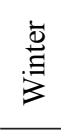 \\
\hline & \multicolumn{5}{|c|}{$\mathrm{m}^{3} \cdot \mathrm{s}^{-1}$} \\
\hline$<\mathrm{AMF}$ & 37 & 0 & 2 & 0 & 0 \\
\hline $\mathrm{AMF}-0,5(\mathrm{AMF}+\mathrm{MALF})$ & 72 & 0 & 71 & 0 & 0 \\
\hline $0,5(\mathrm{AMF}+\mathrm{MALF})-\mathrm{MALF}$ & 92 & 0 & 215 & 0 & 0 \\
\hline MALF - 0,5(MALF+MAF) & 138 & 327 & 56 & 275 & 291 \\
\hline $0,5(\mathrm{MALF}+\mathrm{MAF})-\mathrm{MAF}$ & 6 & 14 & 1 & 51 & 51 \\
\hline$>$ MAF & 0 & 4 & 0 & 19 & 3 \\
\hline
\end{tabular}

The average annual environmental flow value calculated according to hydrological formula, combining the requirements of the MesoHABSIM and Hyd_ben models, for the analysed group of 345 river-gauges, is $51 \%$ higher than Qn according to the Kostrzewa meth- od, and $27 \%$ higher than MALF, but attention is drawn to the variation in the amount of environmental flow in bio-periods.

Therefore, it can be stated that these requirements are higher than those currently in force, and in many cases they may not be feasible to meet from a hydrological point of view. The inability to maintain the environmental flow may be due to the natural hydrological regime, when a significant percentage of days can be expected in a year in which the flow rate in the watercourses will not meet these requirements. Therefore, adopting them as the basis for restrictions on water abstraction, in the form that is currently the case in water permits, may seem too restrictive. Within one year, a large spread of the average value of the abovementioned environmental flow to the minimum acceptable flow according to Kostrzewa is a consequence of the fact that the values of the former are much more concentrated in relation to MALF. The ratio of the yearly average value of the environmental flow (based on the hydrological formula, combining the requirements of the MesoHABSIM and Hyd ben models) to MALF ranges from 1.18 to 1.61 , with the average of 1.29 , where in the case of the Kostrzewa method, the variability of coefficients remains within the range of 0.5 to 1.52 . When analysing the results, it is worth remembering that in the analysed group of river-gauges, there is an overrepresentation of river-gauges in the ichthyological type 4 streams (lowland rivers), and an underrepresentation of river-gauges in the ichthyological type 3 streams (lowland streams).

\section{CONCLUSIONS}

As a result of the implementation of two projects concerning the development of conditions for Polish environmental flows, material was obtained that allows the formulation of a method for determining the channel environmental flow founded on the hydrological formula, based on MALF and coefficients determined based on field research, differentiated for ichthyological and macrozoobenthic types and periods in the development of these living organisms during the year. With the knowledge of MALF characteristics, the hydrological formula (1) and a set of 40 coefficient values given in Table 3 , it is possible to determine the environmental flow by the laboratory method for any SWB, with relatively little workload. However, before 
a decision is made to replace the minimum acceptable flow with an environmental flow, it is worth considering some important observations of the authors:

- The regulation introducing this hydrological formula into the legal circulation should include, in addition to the list of $\mathrm{p}$ coefficients for 4 bio-periods, also a list of SWBs for the area of Poland with their assignment to ichthyological and macrozoobenthic types, and above all it should take into account the methodology for calculating the MALF characteristics in controlled and uncontrolled catchments ${ }^{2}$, which is lacking at present;

- Hydrological formulas (and thus also the Kostrzewa method) generalize the relationships obtained from hydrological analyses or models based on field studies; the results obtained are more "concentrated" due to the averaging of relationships at the cost of compliance with the assumptions behind the source method;

- The formulas are sensitive to inaccuracies in determining the hydrological characteristics underlying the model; in Poland, the unresolved problem for many years has been the development of MALF characteristics for controlled catchments, not to even mention uncontrolled catchments;

- Both compared hydrological formulas are based on analyses of a small number of cases belonging to particular categories of catchments, abiotic or biotic, for which model parameters are averaged. The Kostrzewa method considered river-gauges on 60 rivers, in the MesoHABSIM + Hyd ben method field measurements were made on 34 rivers - could this number of tests be sufficient to make the methods reliable for the whole country?;

- Adopting a method for determining environmental flows, in the form of a hydrological formula based on hydrological characteristics (in this case, annual MALF) and a set of coefficients differentiated for various watercourse categories, assumes similarity of the hydrological regime of watercourses for which identical coefficients are adopted. The verification of this assumption on the set of 345 river-gauges made in the work (KZGW, 2018b) showed a significant differentiation in the variability of flows in watercourses of one type, regardless of the classification. The application of the hydrological formula averaging this variation can lead to significant overestimation or underestimation of the channel environmental flow values for watercourses differing from the average for a given type, whereas methods based on annual characteristics can produce significantly different values from those based on seasonal characteristics. It seems that these reservations concern the Kostrzewa method to a lesser extent than the MesoHABSIM + Hyd_ben method. The application of the habitat model to develop a hydrological method with a formula similar to the most popular method in Poland for determining minimum acceptable flows is a practical solution that is potentially beneficial, because it limits the time and costs of determining environmental flows. Furthermore, it does not cause implementation problems that would be associated with a method that is not currently used in Poland, and would be difficult to implement on a broad scale. On the other hand, there are reservations about the large spread of coefficients in individual biotic types, which, when averaged, are the foundation of the method. As a consequence of averaging, the values of the channel environmental flow may often be relatively high, and they limit the possibilities of water abstraction for a significant part of the year.

Considering the above-mentioned problems associated with the use of hydrological formulas, or more broadly speaking of laboratory methods, one should consider methods based on field studies. Here, in turn, considering the mass-scale use, the challenge is the cost and time needed to get the result. Such solutions, which are outside the scope of this article, were also analysed in the work (KZGW, 2018b).

Summing up, while the authors point out that the project results (KZGW 2018b) make it possible to propose and implement a comprehensive method for determining channel environmental flows for the needs of the new planning perspective 2021-2027, they see the need for a broad discussion in the context of identified reservations.

${ }^{2}$ Unfortunately, the latest amendment to the Water Law Act adopted by the Sejm (Parliament) of the Republic of Poland on September 11, 2019 assumes that it is only by the end of 2021 that a nationwide methodology for calculating MALF will be developed. This calls into question the possibility of using MALF in the planning cycle 2021-2027 for design analyses. 
Grela,J., Madej, P. (2019). Assessment of the possibilities for determining the channel environmental flow based on the environmental requirements.... Acta Sci. Pol., Formatio Circumiectus, 18 (4), 59-70. DOI: http://dx.doi.org/10.15576/ASP.FC/2019.18.4.59

\section{ACKNOWLEDGMENTS}

The present article was developed on the basis of the results obtained in the work "Implementation of the method of estimating environmental flows in Poland", which is part of the project no. POIS.02.01.00-00.0016/16 titled: "Development of the second update of Poland's national water and environmental program and water management plans for river basin areas together with planning documents constituting the basis for their development", co-financed by the European Union from the Cohesion Fund under the Operational Program Infrastructure and Environment 2014-2020 and implemented at the request of the State Water Holding Polish Waters - National Water Management Authority in Warsaw.

\section{REFERENCES}

Arthington, A.H. (1998). Comparative evaluation of environmental flow assessment techniques: Review of holistic methodologies. LWRRDC Occasional Paper 26/98. Land and Water Resources Research and Development Corporation (LWRRDC): Canberra.

Bovee, K.D. (1982). A guide to stream habitat analysis using the instream flow incremental methodology. Instream Flow Information Paper 12, United States Fish and Wildlife Service, Fort Collins, Colorado.

European Commission (2015). Ecological flows in the implementation of the Water Framework Directive. Guidance document $\mathrm{n}^{\circ} 31$. Technical Report 2015, 086.

Grela, J., Madej, P. (2019)., Kalibracja habitatowej metody wyznaczania przepływów środowiskowych korytowych w Polsce. Aura, 3, 3-7.

Grela, J., Stochliński, T. (2005). Doświadczenia w zastosowaniu metody IFIM do obliczenia wielkości przepływu hydrobiologicznego na obszarze Karpat. Gospodarka Wodna, 2, 52-57.

Jowett, I.G. (1997). Instream flow methods: a comparison of approaches. Regulated Rivers Research \& Management $13,115-127$

Kostrzewa, H. (1977). Weryfikacja kryteriów i wielkości przepływu nienaruszalnego dla rzek Polski. Mat. Badawcze, seria: Gospodarka Wodna i Ochrona Wód. Warszawa.

KZGW (2015a). Ustalenie metody szacowania przepływów środowiskowych w Polsce. Etap II raport końcowy. Krajowy Zarząd Gospodarki Wodnej, grudzień 2015 r.

KZGW (2015b). Ostateczna uzgodniona typologia wód powierzchniowych ze streszczeniem. Warszawa, Gliwice: KZGW.
KZGW (2017). Wdrożenie metody szacowania przepływów środowiskowych w Polsce. Weryfikacja i kalibracja metody szacowania przepływów środowiskowych - metodyka i część terenowa. Zad. 1.1.3 Metodyka weryfikacji i kalibracji metody szacowania przepływów środowiskowych, Krajowy Zarząd Gospodarki Wodnej, październik $2017 \mathrm{r}$.

KZGW (2018a). Wdrożenie metody szacowania przepływów środowiskowych w Polsce. Weryfikacja i kalibracja metody szacowania przepływów środowiskowych - część analityczna (wraz z uzupełnieniem badań terenowych). Zad. 2.1 Wykonanie uzupełniających badań terenowych w zlewniach pilotażowych. Raport z badań terenowych I i II etapu, Krajowy Zarząd Gospodarki Wodnej, październik $2018 \mathrm{r}$.

KZGW (2018b). Wdrożenie metody szacowania przepływów środowiskowych w Polsce. Weryfikacja i kalibracja metody szacowania przepływów środowiskowych - część analityczna (wraz z uzupełnieniem badań terenowych) oraz opracowanie narzędzi do wdrożenia metody. Szczegółowa metodyka i opis sposobu wdrażania ostatecznej metody ustalania przepływów środowiskowych, Krajowy Zarząd Gospodarki Wodnej, październik 2018 r.

Milhous, R.T., Updike, M.A, Schneider, D.M. (1989). Physical Habitat Simulation System Reference Manual-Version II. Instream Flow Information Paper 26. United States Fish and Wildlife Service, Fort Collins, Colorado.

Młyński, D., Wałęga, A., Wachulec, K. (2015). Porównanie metod do wyznaczania przepływu środowiskowego na przykładzie zlewni górskiej. Inżynieria Ekologiczna, 44, 184-190.

Olden, J.D., Poff. N.L. (2003). Redundancy and the choice of hydrologic indices for characterizing streamflow regimes. River Research and. Applications, 19, 101-121.

Parasiewicz, P., Dunbar, M.J. (2001), Physical Habitat Modelling for Fish: A developing approach. Large Rivers, 12(24), Archiv fur Hydrobiologie, Suplement, 135 (2-4), 239-268.

Parasiewicz, P., Rogers, JN, Gortazar, J., Vezza, P., Wiśniewolski W., Comoglio, C. (2013), The MesoHABSIM Simulation Model - development and applications. In: Maddock I., Harby A., Kemp P., Wood P. Ecohydraulics: an integrated approach. John Wiley \& Sons Ltd., 109-124.

Parasiewicz, P., Prus, P., Suska, K., Marcinkowski, P. (2018). „E $=\mathrm{mc}^{2}$ ” of Environmental Flows: A Conceptual Framework for Establishing a Fish-Biological Foundation for a Regionally Applicable Environmental Low-Flow Formula. Water, 10, 1501. 
Grela, J., Madej, P. (2019). Assessment of the possibilities for determining the channel environmental flow based on the environmental requirements.... Acta Sci. Pol., Formatio Circumiectus, 18 (4), 59-70. DOI: http://dx.doi.org/10.15576/ASP.FC/2019.18.4.59

Pusłowska-Tyszewska, D., Rycharski, M. (2015). Wymagania wodne ekosystemów zależnych od wód jako podstawa określenia przepływów nienaruszalnych/środowiskowych. Część I: Koncepcja. Gospodarka wodna, 12, $371-376$.

Pusłowska-Tyszewska, D., Rycharski, M., Oświecimska -Piasko, Z., Teodorowicz, M. (2016). Wymagania wodne ekosystemów zależnych od wód jako podstawa określenia przepływów nienaruszalnych/środowiskowych. Część II: Przykłady z Narwi i Baryczy. Gospodarka wodna, 2, 48-60.

Pusłowska-Tyszewska, D., Tyszewski. S. (2014). Wymagania ekosystemów wodnych i zależnych od wód w zarządzaniu zasobami wodnymi. Monografie Komitetu Gospodarki Wodnej PAN. Warszawa. 20, 247-258.

Richter, BD, Baumgartner, JV, Powell, J, Braun ,DP. (1996). A method for assessing hydrologic alteration within ecosystems. Conservation Biology, 10, 1163-1174.

Rozporządzenie Ministra Środowiska z dnia 28 kwietnia 2004 r. w sprawie zakresu i trybu opracowywania pla- nów gospodarowania wodami na obszarach dorzeczy w warunkach korzystania z wód regionu (2004) Dz. U. $\mathrm{Nr} 126$, poz. 1318.

Tennant, D.L. (1976). Instream flow regimens for fish, wildlife, recreation and related environmental resources. Fisheries 1, 6-10

Tharme, R.E. (2003). A global perspective on environmental flow assessment: emerging trends in the developments and applications of environmental flow methodologies for rivers. River Research and. Applications, 19, 397-441.

Więzik, U., Więzik, B.(2006): Metodyka określenia przepływu nienaruszalnego według kryterium hydrobiologicznego w zlewniach rzek i potoków górskich, w Ekologiczne uwarunkowania gospodarki wodnej w zlewniach rzek i potoków górskich, Monografie KGW PAN, 26, 55-73.

Witowski, K., Filipkowski, A., Gromiec, M.J. (2008). Obliczanie przepływu nienaruszalnego - poradnik. Monografie Instytutu Meteorologii i Gospodarki Wodnej.

\section{OCENA MOŻLIWOŚCI WYZNACZANIA KORYTOWEGO PRZEPŁYWU ŚRODOWISKOWEGO W OPARCIU O WYMAGANIA ŚRODOWISKOWE ICHTIOFAUNY I MAKROZOOBENTOSU}

\section{ABSTRAKT}

\section{Cel pracy}

Celem artykułu jest przedstawienie efektów prac nad opracowaniem metody określania przepływów środowiskowych korytowych, która mogłaby być wdrożona jako narzędzie do oceny stopnia możliwego wykorzystania zasobów wodnych przez człowieka bez jednoczesnego uszczerbku dla funkcjonowania szeroko rozumianego środowiska. Metoda taka rozważana jest jako alternatywą dla stosowanych dotąd w Polsce metod wyznaczania przepływów nienaruszalnych, w tym np. metody Kostrzewy.

\section{Materiał i metody}

Przeanalizowano 34 zlewnie badawcze, zróżnicowane pod względem abiotycznym i biotycznym. W pierwszej fazie prac skoncentrowano się na warunkach bytowania ichtiofauny i zastosowano prostą formułę hydrologiczną do oszacowania minimalnych przepływów w rzekach, w oparciu o habitatowy model MesoHABSIM. Następnie metodę poszerzono o uwzględnienie wymagań środowiskowych makrozoobentosu. Dla makrozoobentosu zbudowano zależności przepływu środowiskowego od głębokości wody

\section{Wyniki i wnioski}

Zaproponowano metodę hybrydową, łącząc wymagania habitatowe dla ryb i makrozoobentosu. Zawarto zestaw współczynników do formuły hydrologicznej pozwalający dla każdej rzeki w Polsce i każdego z 4 bioperiodów w roku obliczyć wartość przepływu środowiskowego pod warunkiem znajomości wartości przepływu średniego niskiego. Autorzy dokonali porównania wartości przepływów środowiskowych uzyskanych tą metodą z metodą Kostrzewy, analizując 345 wodowskazów. W podsumowaniu wskazano też słabe strony metody, wynikające z różnorodności reżimu hydrologicznego w ramach jednego typu biotycznego i skutków uśredniania współczynników w formule hydrologicznej.

Słowa kluczowe: przepływy środowiskowe, metody habitatowe, formuła hydrologiczna 